European Journal of Logistics, Purchasing and Supply Chain Management

Vol.8 No.1, pp.19-34, March 2020

Published by ECRTD UK

ISSN 2054-0930 (Print), ISSN 2054-0949 (Online)

\title{
Seaport development as an agents for economic growth and international transportation
}

\author{
Adetose Emmanuel Owoputi \\ Department of Transport Management Technology, School of Management Technology, \\ Federal University of Technology Akure, Nigeria.
}

Capt. Oluwatosin Owoputi Owolabi

Nigeria LNG Ship Management Ltd.

Email : esoteda@yahoo.com GSM. 08029358652

Email: tosinssandd2003@yahoo.com GSM 07055116839.

\begin{abstract}
Seaport remains the most feasible for the activities of terminals, where loading and off-loading of water vehicles, vessel, ships, ferries and all activities to ensure that what comes in or go out are checked to meet the national and international rules and regulation guiding port activities. It is also a point of revenue generation and tax payment on goods and service rendered. The need for a seaport/ terminal is of economic functioning and technological movement and transfer of goods and services, with modern technology equipment and professional managerial ability. This has strong impact on the building or construction of seaport for economic development and international trade. The type of port, size and infrastructures available, and it location, have great impact on it operations. Water transportation has the capacity to carry the heaviest load than any mode of transportation. These made it necessary for the construction of a sea-port to be technically structured in a way to meet the demand of International Maritime Organization (IMO) rules and regulations. The economics and international traders have argued in favour of seaport for exchange of goods at international trade as its relates to global and domestic economic growth and development. There are many allied activities of economic impact at sea-ports and on it environment and the its Communities. This confirmed that positive relationship exist between global trade, port activities, economic growth and development. Seaport development unlock many investment potentials and commercial opportunities to emerge. We use time series data, and International Ports Reports. The Johansen's co-integration test was also conducted to establish relationships between the two variables. We also used Questionnaire and group meeting with the operators, users, and port authority. The results shows that positive development, economic, commercial activities, business, employments, revenue generation, tax, increase in trade and distribution activities occur through seaport development. This shows that. there is need for new seaport development in the Southern coastline of Nigeria, around Olokola area between Ondo and Ogun State. in order to enhance more economic benefits growth and development in international trade and chain supply economic comparative advantage while the other seaport should be up-graded to a standard seaport for greater development within the national increase valve of life.
\end{abstract}

KEYWORDS: seaport; investment opportunities; economic growth; global transportation; national development. 
European Journal of Logistics, Purchasing and Supply Chain Management

Vol.8 No.1, pp.19-34, March 2020

Published by ECRTD UK

ISSN 2054-0930 (Print), ISSN 2054-0949 (Online)

\section{INTRODUCTION}

Seaport remains the most feasible for the activities of terminal, where loading and off-loading of water vehicles, vessel, ships, ferries and all activities to ensure that what comes in or go out are checked to meet the national and international rules and regulation guiding port activities. It is also a point of revenue generation and tax payment on goods and services rendered. Port is always located by the sea shore to enable ships and other water vehicles and documentation with interaction for both land and water transportation activities take place. The need for seaport / terminal are of economic functioning and technological movement and transfer of goods and services, with modern technology equipment and Professional management ability. This has strong impacts on the building or construction of seaport for economic development, international trade, and distribution. Bamide, A. (2017) There are thousands of port of different types and sizes, Globally, with the aim of capturing some market share of freight by sea. The type of port. Its size, facilities, infrastructure available, and it location, have great impact on it operations. Ports are area that are attached to sea, ocean, river by connecting waterways as essentially requirement.

The water transportation has the capacity to carry the heaviest load than any mode of transportation, these made it necessary for the construction of a sea- port to be technically structured in a way to meet the demand of international maritime organization rules and regulations. This is due to the fact that difference sizes, weight, high volume of goods are passing through the sea port for on- ward freight forwarding and distribution. There are many allied business activities of economic impact at the seaport and it confirmed that positive relationship exist between global trade, port activities, economic growth and development.

Seaport development unlock many investment potentials and commercial opportunity to emerge. This is to justify the need for sea port with modern infrastructure and equipment for operation to meet intermodal system. The size of seaport determine the type of water vehicle (ship, boat, ferry and vessels) that can come to the location has better advantage for hosting a seaport than other seaport created for the purpose of meeting the need of that nation where it near a sea-shore.The chosen of a seaport location aid it design and construction to meet demand of global economic activities and the turn- around of water vehicles and cargo clearances for distribution. The environmental community in any seaport area usually have economic revolution growth and expansion, development with migration urban increase in population and traffic . For a seaport to be functional, it has to have infrastructure, space, warehousing, equipment, communication and monitoring signal equipment to meet the unexpected vehicle and activities of the sea-port.

The size of the land, the road network at the seaport, the segmentation of the seaport area:Terminal for handling different cargo, loading of different goods and off-loading points at different terminal points of operation. A modern and efficient maritime infrastructure at seaport is critical to security, economic development, maritime transportation, and cargo 
Vol.8 No.1, pp.19-34, March 2020

Published by ECRTD UK

ISSN 2054-0930 (Print), ISSN 2054-0949 (Online)

movement, vessels operation for freight management supply chains serviced by liner vessels Facilities around the world to achieve the economic desired goal of developing a multi-modal, safe, efficient effective, world-class seaport, that would meet the needs of a modern, vibrant , industrial economy and be a seaport hub for maritime transportation and commercial system, requires an investments in seaport infrastructure at the Federal, Terminal at state and jetties at local government level are needed to be coordinated, well integrated and aligned with one another on a sustainable basis for such a port. Oni. S.I (2003) The challenges of seaport industry is constantly changing in response to and in anticipation of global economic dynamics manifested by environmental and evolutions in shipping:- Vessel sizes, speed, specialization and services, substantial cargo traffic growth, packaging techniques, cargo- handling equipment, Radical change in information, climate, and communication systems and commercial practices, standard in safety and environment management, port management system, private sector investors and Operators.

Countries that are unable to cope with such rapidly advancing infrastructural realities, will find out that they are not in a position to foster economic development of their trade sector being the principal facilitator of $95 \%$ of the world trade including oil and Gas. In its high stakeholder engagement ratio for policy and regulations and its challenging technical principles and applications. Badejo (2012) The substantial growth of maritime shipping has resulted in large quantities of goods and products being transported around the world, creating a demand for innovative solutions for infrastructure and fleets. A further increase in the scale and the size of container carriers and passenger cruisers also requires special facilities. These development have presented a challenge for different types of technologies, as well as operational system. Maritime transportation, should be integrated with other services, such as railways, roadways and airports, while in some cases rivers, canal traffic in order to achieve maximum efficiency. Owoputi (2018).

Sea port needs to respond rapidly to the economic and political circumstance in different parts of the world. The research into the deeper and natural sea- harbor in the coastal belt of Ondo -Ogun state coastline indicate that the land and sea belt of Olokola area could be developed into a sea-port hub for west Africa region. Looking at the location, a global goals and objectives with economic resources, viability of deep-water of natural seaport construction should be considered, the size of the water, land and position of the location for West Africa coastal region and industrial development and large inter- land network for trades shipping, and cargo redistribution, will greatly take care in the planning with the numerous mineral deposit in that region yet untapped, i.e. Bitumen, oil and gas.

The extensive trade networks of the global trade shipping world has contributed largely to the success of seaport development and civilization spanning wider than before. With the resources they need to sustain settled population levels in the several cities of the world over. Musso- Enrico (2006). Seaports played an immense role in trade, commerce, and politics even during early ages. A harbor is a place where ships can seek shelter, while "Shelter" must include Anchorages, landing places on beaches and ports with structures like, access channels, breakwaters, jetties, landing stages quays, warehouses for storage of 
Vol.8 No.1, pp.19-34, March 2020

Published by ECRTD UK

ISSN 2054-0930 (Print), ISSN 2054-0949 (Online)

commodities and equipment, ship sheds and shipways for ship. Seaports location are selected to optimize access to land and navigable water for commercial demand and for shelter from wind and waves. Harbour can be natural or artificial. An artificial harbor has deliberately constructed break waters, sea walls or jetties or otherwise, they could have been constructed by dredging and these require maintenance by further periodic dredging. A natural harbor is surrounded on several sides by prominences of land. Seaports are one of the primary component of the general transportation sector and are nowadays linked to the expanding world economy.

Seaports are basically a means of integration into the global economic system. The maritime sector encompasses a wide range of services, pilotage, towing and tug assistances emergency repairs, anchorage berth and berthing services and other auxiliary or allied supporting services. Within the port area, a great diversity of activities are performed, infrastructure services generally provided by port authorities. Cargo handling services in most ports provided by port authorities, cargo handling services. Sea conveyance is the cheapest way of transportation when considered in terms of fuel consumption and investment. When compared to other transportation systems railways transportation requires twice as much energy consumption, while road transportation requires ten times as much as sea conveyance. In the past few decades, the world has becomes increasingly environmentally conscious and with its lower energy consumption, marine transportation is obviously more environmentally friendly than others means. Dwarakish et, la (2015).

The international trade regime allowed manufacturers to relocate their production and assembly plants to a more cost- efficient locations in developing economies, in turn generating a new spatial division of labour. Massey (1984). The seaport is the medium through which goods originating from and destined for different parts of the world are transported. Seaports in relation to trade are major gateways to the economy of nations hence, It play an important role in the development of the country .

In Nigeria, it is incomprehensible and unjustifiable why all the seaport are focused on congested Lagos, when other equally viable ports that should be developed to decongest the metropolis have been curiously abandoned. That all the functional ports Apapa and Tin Can Islands are Lagos based ports and new ones are being Planned for Lekki and Badagry which will increase and become endanger for Nigerian and its commercial center Lagos. It is an abandoning the other area in the western coastline and south- south axis that should be developed to decongest Lagos.

It was find out that the other ports in Calabar, Port Harcourt, Warri and Onne are not fully utilized due to some infrastructural lapses, and lack of modern port facilities, and professional manpower and management policy. Of recent the planned Badagry seaport project was cancelled because the Agency has begun the process for fresh bid for the approval of a new port master plan for the deep seaport project. The Lekki purposed seaport will only contribute to the hardship of life and business, commercial activities of Lagos in general. . In Lagos there is no efficient and sufficient rail system. It would be 
Vol.8 No.1, pp.19-34, March 2020

Published by ECRTD UK

ISSN 2054-0930 (Print), ISSN 2054-0949 (Online)

foolhardy to compound the gridlock by building another seaport in Lekki or Badagry. The issue was political and the government responsibility was put in Outline Business Case $(\mathrm{OBC})$ by the ministry of transport which was referred to port Act within stipulated responsibilities for provide of some services, due to issues of obligations of NPA.

The United Nations Economic Commission for Africa [UNECA] has proposed the used at country level to assess and monitor constrains faced by the private sector as they trade in Africa. Having such an index that assesses and monitors shipment enabling factors including tariffs and non-tariffs measures and induced costs faced by private sectors, operators will help to deepen the implementation of the AFCFTA. The rationale is that private businesses are the target beneficiaries of the AFCFTA. It is them that actually trade across borders to whom the AFCFTA should serve. By putting the private sectors at the heart of monitoring the effectiveness of the AFCFTA, the ACBI will encourage countries to effectively implement the AFCFTA in the interest of those for whom its designed, Tahar, Jouili (2016).

Some seaport business currently face many constraints in area of professional skilled manpower, human resources with practical Know-How, including high trade costs divergent regulatory frame- works and governance issues that undermine their Total Quality Management Technology System and Effective Operations on the African seaport continent. These bottleneck are expected to be addressed by an effective implementation of the Agreement. There is a need to develop tools and instruments that help countries capture the effectiveness of measures undertaken to implement the agreement with a view to increase business competitiveness and PPP system in seaport building, management and supervision, Sibel, B (2011).

Ports produce a combination of public and private goods. Public goods include those that are inherently non-divisible and non consumable, such as public safety, security and a health environment on hand, and coastal protection works necessary to create port basin on the other hand. Private goods are both consumable and divisible and their use entails a minimum of economic externalities . Large ports offer-particularly attractive locations for seed industries and distribution intensive businesses several notable port - centered industrial clusters have developed over the last 50years for example:- Dubai, Colon, Norfolk, Antwerp Retterdam, Yokohama and Marseilles etc. As a matter of strategic development policy many seaports encourage the co-development of various valued- added services through franchising, licening, incentive leasing. Globally, seaports seeks to attract enterprises that extend their logistics chains or provide them with allied businesses and specialized capabilities to add valve to cargoes that are stored and handled in the port. Park J. S. (2016).

Many governments are directly or indirectly involved in seaport development, Some government use "Growth pole " argument to justify the direct financing of basic seaport infrastructure. The seaport operations are businesses in their own right and should be managed to achieve optimal utilization of capital investments in seaport assets are affected 
Vol.8 No.1, pp.19-34, March 2020

Published by ECRTD UK

ISSN 2054-0930 (Print), ISSN 2054-0949 (Online)

by risk, competition for land and capital or other factors in the competitive business environment. Seaports are managed under a complex legal concept and managed through an organizational model that mostly generates the need for convergence of the public and private sectors. The management model used in Spanish territory is fairly standardized the model is infrastructure is publicly owned and serve delivery tends to the private and regulation is carried out by a public official. Bofarull (2010).

\section{Developed Nations Seaport Impacts;}

Among the transportation infrastructure, seaports have been massively studied in the recent years Contributes to the economic growth. Recently the findings of these studies showed that there are positive relationship between seaport investment and economic growth. Most previous researchers used a production function approach to estimate the effects of seaport investment infrastructure on economic growth. In China and Korea, it estimated the effects of seaport on economic growth using time series data. A significant and positive effect of the seaport on the economic growth is found in many nations. Uniquely for China, Song et, la (2014) concluded that seaport has a positive effect on state or regional economic growth, but with obvious differences at the regional and provincial level. In china as well Shan ( 2014 ) have confirmed the positive impact. On the whole three conclusions were made. (a) The seaport containerized cargo flow of larger seaports is more significantly associated with the economy than that of smaller ones. (b) The number of cargo through out of competing seaports exhibits a positive effects on a nation economy - (c) The seaport cargo throughput significantly impacts the host state or communities economic growth.

For the Tunisian seaport, Jouili T. (2014) concluded that seaports play globally a key role in the economic growth. He shows that seaport have a significant impact on the economic growth, the elasticity of seaport infrastructure is 0.072 . This elasticity reflects the global impact of seaport infrastructure on the economic growth, while it cannot reflect seaport's contribution in the growth sectors. 


\section{SEAPORT DEVELOPMENT ACTIVITIE}

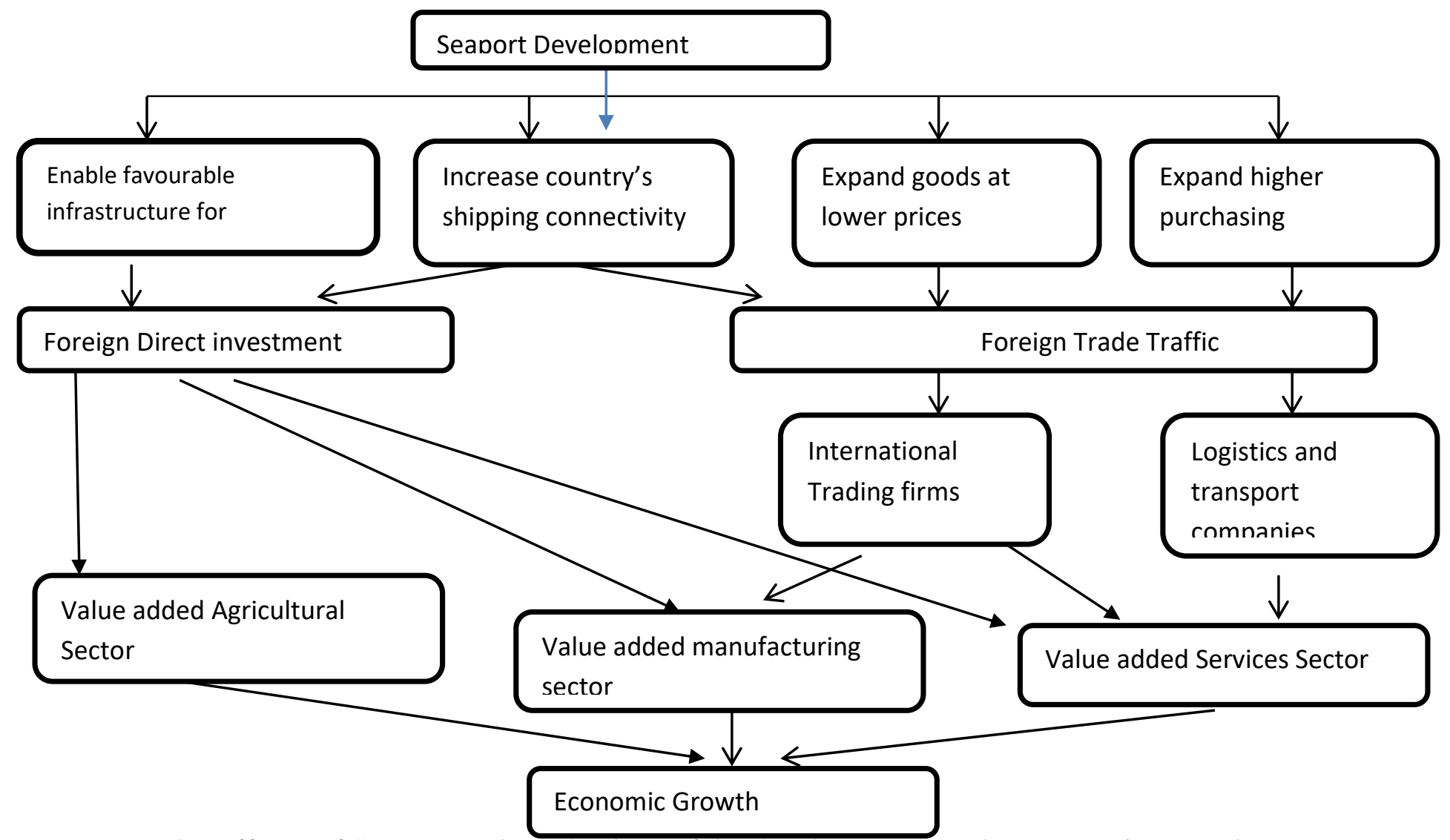

The effects of Seaport and Mechanism of its development on the economic growth.

Source:- Jouili, T. A and Allouche M. A

\section{The economic pull of port on development}

The mutual benefit of port has been established in the economic development of both local and national which states that in spite of job cuts in traditional port activities such as warehousing, ship repair, stevedoring bunkering, freight forwarding the seaport remains sustainable as it gives a long term basis on it functions of many different kinds of allied business are expected to develop in the local area. The (seaport maritime) activities has a relatively close relationship with both urban and port system in Nigeria. The transportation activities facilities foreign trade, Technology in transport system to enhance interdependency among economies in the global world. This is through the support of seaport.

The European regions Bottasso et, la (2014) analyzed the important of seaports activity on the regional GDP [ 621 regions] and focusing on it spillover effects on the neighbouring regions. He indicate that ports tend to increase GDP in the area, where they are located (direct effects ) and effect positively the GDP of nearby nations. The seaport development 
Vol.8 No.1, pp.19-34, March 2020

Published by ECRTD UK

ISSN 2054-0930 (Print), ISSN 2054-0949 (Online)

could affect the economic growth through many channels It is expected that seaports affect economic sectors and afterward the economic growth.

The term "Cartelistic for economic growth" includes all the change as regards the demand for goods and services, and contribution to tax revenue, employment that can be attributed directly and indirectly to the transport infrastructure presences Carlucci F. Cira (2009).

\section{Functions of Ports}

Ports function as important gateway of international trade and port is regarded as major accelerators of local economic development in the age of globalization.

Usually port- city interface are reviewed and input- output linkage effect of ports are numerous. The impact or transportation and communication technology and the free- market ideology have given rise to easy mobility of goods and services, including passengers. The world has rapidly integrated into one global market [economy]. The sea, as a major route that provides low cost and massive transportation means.

In 2008 about 77\% of the total world international freight was through maritime mode. This made port and shipping industry played a great role in distribution of goods and services both locally and international economic growth. Large quantity of raw materials and Agro- products would have be wasted and valueless if there were no shipping of such products through seaport to the area of high needs of such raw materials at international market for their industrial production of either semi-finished product or finished product like cocoa, Rubber, Groundnut , Cotton, Limestone e.t.c. It highly dependent on sea port services which has low cost mass transportation means.

Seaport and heavy weight goods for domestic and international trade, industrial development, exchange of valuable products are expected to be shipped through seaport which have positive influence on economic development in both local and foreign nations. Therefore port have been considered to be the engines of economic development, industrial location and distribution hub of goods and services. It has being creating significant direct local employment and value added production effects. The Nigerian seaport are located along the Ocean coastline of the country. This is to take advantage of economic globalization and utilization of the coastline of the country. The existing seaport along the coast are not functioning at equal per due to some facts. But the Lagos seaports are over used and it always result into congestion, delay, lack of warehousing poor loading and off- loading equipment due to lack of space with the area, this was as a result that at the establishment of Lagos port it was not planned as a continental hub Centre but as a local economic development to service the export intention of the Colonian masters then.

Now the relatively low cost of ground transportation has reduced the advantage of distribution of services, goods locating near a seaport. With globalization international business are likely to be located where land are relatively cheap for industrial location and where professional skill manpower qualified labour resources are easily available. The costs of proximity to the seaport have increased overtime due to traffic congestion. Another reason why a new port is required is that the process of goods movements has become more difficult and much more capital intensive due to containerization and technology system.In Lagos seaport, the research find out that the spatial shifts of port related activities and lack of space and congestion at the port city( Apapa) 
Vol.8 No.1, pp.19-34, March 2020

Published by ECRTD UK

ISSN 2054-0930 (Print), ISSN 2054-0949 (Online)

interface. With Lagos port, it was a role of simple transit of cargo between land and sea, then loading and off- loading of cargo was primary function of seaport Authority, later other basic logistics activities such as storing, distribution function were added to the function of ports.

But now value added logistics activities had been added as production during transportation, which is in the vicinity of the seaport e.g. inventory control, final assembly, and managing goods, create information flow, labeling, customizing, configuration, blending e.t.c. These are example of value added logistics activities among others. This has add value to the economic development of the Nation.The transportation activities facilities foreign trade, Technology in transport system to enhance interdependency among economies in the global world. This is through the support of seaport. The movement of goods, services and passenger across border aid the promotion of international relationship, export development for export products oriented value added and increase foreign exchange, This will add value to the nations seaport usage and upgrade with certain advantages.

\section{Issues in new seaport:}

1. Change in transportation system in the Area.

2. Environmental development and increase in valve.

3. Reduced the Cost and time required to pack, move and handle cargoes

4. The extension of the hinterland around the port to overlap hinterland

5. Security for cargoes generated by nearby Town/cities

6. The growth in maritime vehicle sizes and

7. The need for shipbuilding and Stevedoring technology advances

8. Deep berths investment

9. Wide Terminals usage and freight increase.

10. Narrow midtown area with shallow water ways

11. Port in the same region becoming a closer subtitles

12. The connection between ports and regional economics becoming weakened

13. Logistics technology will result in collapse of market power of poets in that area

14. Spatial closeness does not guarantee Port to handle cargoes from hinterland

The demand for port services is derived from activities of economic sectors other than port industry itself.Seaport industry can only be successful with production activities of other sectors. The economic activities of hinterland are imperative for the success of any seaport, Arne Nilsen (2018).Major reasons while new seaport ( Olokala ) deep sea] should be developed to standard.. With the location of that seaport site which is of many numerous mineral resources and Agricultural products that will act as captive cargoes such as dry bulk, oil and gas, bitumen, palm oil, timber etc. Are required to be handled at nearby ports because of excessive cost inland transportation connecting their origin/ destination and the port.Attachment of such captive cargoes to nearby ports is self-explanatory and it is meaningless to discuss port-city interface for them here. At the early stage, the seaport will attract economic development, export oriented raw material processing and heavy industries have to settled around it. The usual Export processing zone will be greatly influence and lead to advantage and economic development, social 
Vol.8 No.1, pp.19-34, March 2020

Published by ECRTD UK

ISSN 2054-0930 (Print), ISSN 2054-0949 (Online)

advancement, because efficient and low cost transport service is readily available in the vicinity of the new seaport.

The port will play an important role for the heavy mineral resources industries such as bitumen, Gas and oil, Timber and other Agricultural products. As steel shipbuilding, petrochemical industries which Nigeria economy would supported. Internationally, heavy / petrochemical, bitumen industries could not be viable without low cost mass transportation means of shipping. The location of Olokola deep seaport development near industrial complexes and industrial export processing zone will be well developed. Since global trade always relied heavy on maritime transport the site and location justifiable a sustainable investment and it will be a great gateway seaport for international shipping and logistics activities. It will assumed the function of hub activities to import raw materials, and to export manufactured goods. The other abandoned seaport could be developed in major centers of economic activities in their area of locations.

To succeed, the seaport is required to be integrated into global supply chain by achievement $\mathrm{f}$ higher freight coordination and cooperation. The seaport will developed mutual prosperity for future economic benefits generating from it important linking modes in the logistics chain. The seaport Will integrate it's activities into the national economies The business environment will enjoy high connectivity to the global world.The business to create employment opportunities and revenue, income value added logistics activities Allied port activities will be developed to easy and contribute to socio- economic development of the society like:- Tran shipment demand and other transit activities of production and consumption. The issue of environment management should be harmonized by relevant professional skilled manpower, as reduction of carbon emission from seaport operation, creation of green buffer zones, warehousing.

Therefore this paper focused on the need for new seaport development along southwest coastal waterline as a cater lied for economic development.

\section{RESEARCH FINDINGS}

The finding shows that the issue is not who does what at the port but the rationale for building another port in Lagos when the city is daily choked with a killer traffic gridlock. The Olokola in Ondo / Ogun state boundary which is a natural seaport harbor, could have being the best and a better location for a new seaport which all the above stated factors that favour the location. Some years back, Federal government had emphasized the need to establish deep seaport to decongest Apapa ports. The Olokola should be given priority more than to continue to build new port in Lagos state area, while Port Harcourt, Calabar, and Onne should be up-graded to a modern equipped infrastructural technological mechanized seaport with professional manpower operators. It could be a private, public and partnership (PPP). Port, this will attract investor which is in many developed nations. A port master plan that would be comprehensive enough to guide on what need to be put together for the successful building of the natural seaport at Olokola area. Assess constraints to shipment trade through the recently launched African Continental Free Trade Area [AFCFTA ] is expected to be a game - changer for Africa and a key engine of economic growth, Industrialization and sustainable development of the continent in line with the Africa Union 
Vol.8 No.1, pp.19-34, March 2020

Published by ECRTD UK

ISSN 2054-0930 (Print), ISSN 2054-0949 (Online)

[AU ] Agenda 2063. The regulations and policies which undermine the functionality of market institutions needs to be identified and addressed.

\section{Port Activities $2013-2016$ and It Economics Value in Nigeria.}

The port activities traffic report statistics was with a total number of 19,833 vessels berthed at various ports between 2013-2016 while 543842,425 tonnages were registered within the period under review. Year 2014 recorded the highest number of vessels berthed as well as tonnages registered while the least were recorded in 2016.Tin can island port handled the most ships accounting for $33 \%$ of total number of ships that berthed in all ports and $32 \%$ of total tonnage registered in all port and $32 \%$ to total tonnage registered in all post. It is closely followed by Apapa port which accounted for $28 \%$ of ships that berthed and $25 \%$ of total tonnage registered and One port which account for $15 \%$ of ships that berthed and $30 \%$ of total tonnage registered. Cargo traffic statistics revealed a total of 312,185,808 cargo traffic was recorded at all Nigerian ports between 2013 and 2016, 196,851,236 or $63 \%$ of the cargo traffic were inwards while $115,334,572 \quad$ or $37 \%$ were The number of passenger's traffic within the period under review was put at 52,262 while the highest number of passenger traffic was recorded in 2013.

Seaport activities indicates the facilities created for the following :-

* 1513 direct jobs

* 1308 induced jobs were supported by the purchases of 1513 directly employed individuals

* 560 indirect jobs were generated as a result of 46.9 Billon Naira of local purchases by firms directly dependent upon seaport activities at all the seaports.

* The 1513 direct employees earned over 61.1 million of wages and salaries, for an average salary of 960,000 per year.

*Business providing services for the cargo activities received 258.9 million of busness revenue.

* About 25,6 million of State and Local taxes were generated by seaport activities.

* 1174 jobs of the coastal inland water transportation related to the cargo and passenger movement, terminal, canal and river ferries services, distribution and storage of different products as well as petroleum products, bulk cargoes used for local construction activity. Three millions of employments impact of the cargo activities at seaport/jetties while a lot of direct employment impact on the economic growth can be linked with transportation.

Surface Transportation

Truck over

Maritime Services

Terminal employment

Towing / pilotage/ Line Handling

Agents

Maritime / Services

Marine Consultants / Ship Yards

Government

Port Administration
Direct Jobs

1000

2000

100

80

200

300

250

300

400 
Vol.8 No.1, pp.19-34, March 2020

Published by ECRTD UK

ISSN 2054-0930 (Print), ISSN 2054-0949 (Online)

Jobs are measured in term of full- time worker equivalent. Without physical access to jobs, health, education and other amenities the quality of Life suffers and without physical access to resources and markets, growth stagnates and poverty reduction can not be sustainable.( the World Bank Group $2018 \mathrm{CBN}$ ) An over view of the state of the economy, economic analysis and Forecasting role of transport in the economy with impact of seaport activities on seaport development that required intervention in alignment with economic growth development plan for 2030 vision. The long term potential growth rate for Nigeria under the current policy, environment has been estimated at 3.5\% (n world Bank Group 2015) The National government has the ambition of reaching a growth target of 5\% by 2030 .

\section{Exchange rate and Competitiveness in Development}

The U S dollar continues to strengthen against both developing and developed market currencies on expectations of higher growth and interest rates. The national development themes and seaport development with Free Export Trade Zone initiative as out lined in the development plan, will shape economic policy and development over the medium term. The NDP 2030 has an overarching objective to eliminate poverty and reduce inequality. The NDP 2030 proposals to increase employment and growth include the following:- More seaport / terminals and jetties, raising exports by focusing on industries with comparative advantages. Develop rail lines and expand road network with major rivers developed for waterways which will result into :-

(i) Network Effects:- Linking more locations exponentially increases value and effectiveness of seaport and transportation, more jobs and the effect of enhancing the frequency of services. (ii) Intermodal connectivity, projects may enhance the frequency of air, marine or rail services or breadth of origins and destinations.

(iii) Performance improvement:- reducing cost and time for existing passenger and freight movement and increase transport's contribution to economic growth.

(iv) Reliability :- Improves times performances and reduces loss and damages, reduces inventories, centralize warehousing and delivery processes leading to gain in Supply chain benefits.

(v) Market size :- access to wider markets adds to economics of scale in production distribution and consumption,

(vi) Production :- Transport increases productivity gained from access to a large and more diverse base of inputs such as raw materials parts energy and labour and broader market for more diverse output.

The research shows the need for the new seaport at OLOKOLA natural harbor seline and it likely effects on the development growth in Ondo / Ogun state area and generally in the nation's and West African sub-region development. It show that globally investment on seaport has positive influences on the economic groth. The Finding shows that seaport serves more to the services and manufacturing sectors them the Agricultural sectors. The finding also shows that seaport development could be generating economic benefits but it could develop a kind of imbalance between various economic sectors.. To avoid such 
Vol.8 No.1, pp.19-34, March 2020

Published by ECRTD UK

ISSN 2054-0930 (Print), ISSN 2054-0949 (Online)

an inequality the decision - makers should take into account all sectors in the orientation of all new seaport investments.

\section{Port project description international requirement standard.}

The investment facilities required for the seaport in a deep-sea and free trade zone(FTZ) Around olokola in the coastline area of Ondo state has an integrated multipurpose deepsea port complex serving as an oil and gas logistics base and export processing zone. This type of project should be located in an area from latitude 06820 north and longitude 0430 east on the Atlantic coastline, northwest of ESCRAVOS AND AIYETORO. This is approximately $128 \mathrm{~km}$ Escravos, midway between Escravos and Lagos, a $45 \mathrm{~km}$ East of Lekki-Lagos and 400km west of Onne Port Harcourt. The 10,000 hectare of expanse land has been acquired for sea port without development since 2009 the location is in the southern side of about $10 \mathrm{~km}$ along the shore of the Atlantic ocean

Unlocking investment potential in the Africa had itself to blame for it backward in the scheme of things in the period between independence and sometimes in the 90s. An underlying growth in trade in the global economy is driving an increase in shipping and correlated need for increase efficiency and capacity of ports, marine and industrial structures. The key success factor for a seaport development focus o the ability to operate cost efficiently, safely and reliably. Port also need to operate sustainably in a community, within a sensitive near shore environment, and align with government and regional development agenda. The major requirement for any seaport includes: , planning and approvals projects design, construction, operations and maintenance, through to closure which provides a full integrated services across the following sectors.:-

*Ports and Harbours design, including lay outing break-waters, navigation assessments and wave penetration studies.

* Dry bulk terminals, including Port part of a mine development, rail and port bulk transport solutions.

*Oil and Gas terminals.

* Container terminals and dry port intermodal terminals,

* Multi-purpose terminals

* Transshipment facilities

*Ferry terminals

*Coastal management / protection

* Small craft facilities and water front development

There are a lot of investment opportunities in the seaport area, the free-trade zone and Export processing zone, the small scale industrial sectors. This is toward accelerated economic development and stimulate private sector investment incentives are provided for would be investors in all segments of the seaport activities, especially those activities that are export oriented. * Shipping services, as stated earlier A total inbound and out bound of Nigeria market accounts for over $68 \%$ of seaborne traffic into west and central Africa sub-regions. Nigeria as the largest trading port south of Sahara attracts high volume of import trade 
Vol.8 No.1, pp.19-34, March 2020

Published by ECRTD UK

ISSN 2054-0930 (Print), ISSN 2054-0949 (Online)

from major trading regions of the world e.g. Western Europe, Asia- Pacific These traffics are mainly high value finished and semi-finished containerized goods for the local economy and sub-regional market. The traffic is gaining more growth momentum in the current $21^{\text {st }}$ century economic reforms to stimulate growth through increased investment, trade. Export in Agricultural products, industrial raw materials and semi- finished goods. *Tanker shipping:T he gas trade looks very active in the future as the National target on zero flaring. It will create robust trade for gas carrier operators especially National carrier operators. Apart from petroleum products, industrial chemicals constitute major import component opportunities, investment in VLCC, Aframax, Suez ax remain tankers commercial viable economic activities and trade. *Bulk shipping :- The bulk trade is equally promising as the Nation's depends heavily on imported grains, Fertilizer, Sugar, Flour, cement for the domestic market. Tis is expected to continue for a long period due to expansion in population development and urbanization. Importation of certain grains may perhaps remain permanent.

\section{CONCLUTIONS AND RECONMENDATION}

The relationship between seaport Infrastructure, Transport, Services and economic development performance could serve to accelerate economic growth and development, alternatively a lack therefore of it could constrain the potentials for expansion. The composition and performance of the national economy has a specific demand for Trade, Transport, seaport infrastructure and economic growth services.

Cognizance of the economic structure and macro-trends locally, regionally and globally would allow for the adjustment of the development of seaport and transport infrastructure and services to meet the demand as required by economic activities for development.

The research has identified some salient economic impacts:-

* The tertiary sector has experience significant growth in their seaport development, this shows that the economic activities that constitute this fast growing sector grouping have a specific trade / transport requirement which is likely to be different to that of other industries.

* Provincial development Profiles:- The research shows that there might be a divergent mix and levels of seaport infrastructure and transport / trade activities services that required organization and individual support growth paths. National trade patterns:-

*This was identified in the analysis of available data to determine the share of trade in value with other nations.

* This shows that there are urgent need for more seaports development with modernization of transport system to increase economic development growth on regional corridors and port post efficiency improvements.

*The economic framework is the context in which planning takes place. Bue to the dynamic nature of national and global economics demands from traders and chain supply needs transport infrastructure and service over time.

* The economic forecasting and global trade trends is important in determining the timing and quantum of Large scale operation planning interventions to allow the support of an improved national economic performance.

* Seaport has a broader role in shaping development and the environment, policy concerns and revenue generation, job creation, industrial development will increasingly be focused on 
Vol.8 No.1, pp.19-34, March 2020

Published by ECRTD UK

ISSN 2054-0930 (Print), ISSN 2054-0949 (Online)

the effects of seaport activities on where people live and on where businesses locates, industry location decisions have on land use pattern, congestion of seaport area with transportation systems use of natural resources for overall quality of life.

* To effectively achieve Development growth, seaport / transportation needs to be taken With very important financial investment in location and development of seaport and transport distribution of the economic activities, spatial development and planning are $\mathrm{n}$ therefore important consideration for any integrated economic development activities. The seaport will develop mutual prosperity for future economic benefits generated from its services linking nodes in the logistics chain.

The seaport will integrate it activities into national economic growth.

The business environment will enjoy high connectivity to the global world.

It will create businesses, employment opportunities, revenue, tax, income, value and a added logistics and transportation activities.

Therefore its advised that the activities and it allied related services should be harmonized by relevant professional skilled manpower.

\section{References ;-}

Arne Nilsen, Tim labett, Andrew Whiting ( ) Shipping Ports and Harbour Terminal Design and Construction

Badejo Bamidele ( 2012 ) "Towards Achieving effective seaport regulations" Presented at a seminar on ports terminal and logistics, organized by Admiralty Resources Services, Lagos , June 2010.

Bamidele A, Badejo, Oldele M. Solaja (2017) The Nigerian seaports and development 1900 -- 2015. Historical perspectives and dynamics, International Journal of Development and sustainability. Vol.6 pp. 1007 - 1024.

Bofarull, M. (2010) El Sistem Portuario Espanol, Entorno Competitive Y. Resultados. Una Aplicacion del Analisis Envolvente de Data. Universidad Revila.

Bottasso A., Conti M. Ferrari C, Tel A. (2014) ports and regional development, a spatial analysis on a panel of European regions. Transportation research part A. Policy and Practice pp. 44 - 55.

Business sand Maritime Newspaper 92014 ) Apapa The endangered port city. \{https;// businessand maritime westAfrica.com shipping development. Pp. 1-14.

Carlacci, F. Cira A. (2009) Modeling a plan for seaport investments through a system dynamics approach, pomoestve.god pp.405-425.

Dwarakish G. S , Salim A M. (2015) Review on the role of ports in the development of a nation. Aquatic procedia 2015, Available from www. Scien cedirect.com.

Jauili T, Allouche M. A. (2014) The impact of public investment in seaports infrastructures on the economic growth, the Tunisan context, International Journal of Management research and development, pp.25 -33.

Massey, D. (1984) spatial division of labour, social structures and the geography of production.

Musso, Enrico, Ferrari, Claudia, Benacchio, Marco (2006 ) Port investment, profitability, economic impact and financing, port economics, research in transportation economics vol. 16, pp.171 - 218 . 
Vol.8 No.1, pp.19-34, March 2020

Published by ECRTD UK

ISSN 2054-0930 (Print), ISSN 2054-0949 (Online)

Oni, S. I. (2003) Port cities environment and infrastructural planning: case of Lagos, Nigeria. COPE DEC VI Colombo Sri-Lanka paper no. 48.

Owoputi A. E. , Ifabiyi. I.P. and Akpudo U. C. (2018) opportunities and challenges of waterways transportation in the coastal cities of southwestern Nigeria. The Planning research Journal of University of Moratuwa, pp.10 - 17.

Park J. S , Seo. Y. J. (2016) The impact of seaports on the regional economies in south korea; Panel evidence from the augmented Solow model. Transportation research part E. Logistics and transportation review. Pp. $107-119$.

Shan J. Yu M, Lee C. Y. (2014) An empirical investigation of the seaports economic impact; Evidence from major parts in China. Transportation research part E. pp.41 -53 .

Sibel B. C. Gulsum A, Guler A. (2011) The impact of seaport investments on regional economics and developments, International Journal of Business and Management Studies Vol. 3 pp333-339.

Song L. Van Geenhuizen M (2014) Port infrastructure investment and regional economic growth in China, Panel evidence in port regions and PR evinces, transport policy. Pp. $173-183$.

Tahar Jouili (2016) The role of seaport in the process of economic growth, (www.iiste.org, ) developing country studies vol.6 pp. $66-69$.

World Bank ( 2016 ) Logistics performance, indicators, connect to compete Washington D.C. World Bank

World Ports Sustainability Program (WPSP) Charter (2018) International Ports and Harbours Association, American Association of port Authorities (AAPA). European seaports Organization (ESPO) International Association of cities and ports (AIVP) and World Association for waterborne transport Infrastructure (PIANC) Antwepen IAPH.

https://www.constructconnect.com (2018) Port Infrastructure Construction on the rise. 